\title{
Unusual stratospheric ozone anomalies observed in 22 years of measurements from Lauder, New Zealand
}

\author{
G. E. Nedoluha ${ }^{1}$, I. S. Boyd ${ }^{2}$, A. Parrish ${ }^{3}$, R. M. Gomez ${ }^{1}$, D. R. Allen ${ }^{1}$, L. Froidevaux ${ }^{4}$, B. J. Connor ${ }^{2}$, and \\ R. R. Querel ${ }^{5}$ \\ ${ }^{1}$ Naval Research Laboratory, Remote Sensing Division, Washington, DC, USA \\ ${ }^{2}$ BC Scientific Consulting LLC, Stony Brook, NY, USA \\ ${ }^{3}$ Department of Astronomy, University of Massachusetts, Amherst, MA, USA \\ ${ }^{4}$ Jet Propulsion Laboratory, California Institute of Technology, Pasadena, CA, USA \\ ${ }^{5}$ National Institute of Water and Atmospheric Research, Lauder, New Zealand
}

Correspondence to: G. E. Nedoluha (nedoluha@nrl.navy.mil)

Received: 06 January 2015 - Published in Atmos. Chem. Phys. Discuss.: 24 February 2015

Revised: 28 May 2015 - Accepted: 01 June 2015 - Published: 19 June 2015

\begin{abstract}
The Microwave Ozone Profiling Instrument (MOPI1) has provided ozone $\left(\mathrm{O}_{3}\right)$ profiles for the Network for the Detection of Atmospheric Composition Change (NDACC) at Lauder, New Zealand $\left(45.0^{\circ} \mathrm{S}, 169.7^{\circ} \mathrm{E}\right)$, since 1992. We present the entire 22-year data set and compare with satellite $\mathrm{O}_{3}$ observations. We study in detail two particularly interesting variations in $\mathrm{O}_{3}$. The first is a large positive $\mathrm{O}_{3}$ anomaly that occurs in the mid-stratosphere $(\sim 10$ $30 \mathrm{hPa}$ ) in June 2001, which is caused by an anticyclonic circulation that persists for several weeks over Lauder. This $\mathrm{O}_{3}$ anomaly is associated with the most equatorward June average tracer equivalent latitude (TrEL) over the 36-year period (1979-2014) for which the Modern Era RetrospectiveAnalysis for Research and Applications (MERRA) reanalysis is available. A second, longer-lived feature, is a positive $\mathrm{O}_{3}$ anomaly in the mid-stratosphere $(\sim 10 \mathrm{hPa})$ from mid-2009 until mid-2013. Coincident measurements from the Aura Microwave Limb Sounder (MLS) show that these high $\mathrm{O}_{3}$ mixing ratios are well correlated with high nitrous oxide $\left(\mathrm{N}_{2} \mathrm{O}\right)$ mixing ratios. This correlation suggests that the high $\mathrm{O}_{3}$ over this 4-year period is driven by unusual dynamics. The beginning of the high $\mathrm{O}_{3}$ and high $\mathrm{N}_{2} \mathrm{O}$ period at Lauder (and throughout this latitude band) occurs nearly simultaneously with a sharp decrease in $\mathrm{O}_{3}$ and $\mathrm{N}_{2} \mathrm{O}$ at the equator, and the period ends nearly simultaneously with a sharp increase in $\mathrm{O}_{3}$ and $\mathrm{N}_{2} \mathrm{O}$ at the equator.
\end{abstract}

\section{Introduction}

Observations of total column ozone $\left(\mathrm{O}_{3}\right)$ show that, over most of the globe, $\mathrm{O}_{3}$ loss has leveled off since $\sim 2000$, and $\mathrm{O}_{3}$ has even begun to increase. The large decline observed from the 1960s to the late 1990s has ended as a result of the reduction in chlorofluorocarbon (CFC) emissions following the 1987 Montreal Protocol (WMO, 2014). While global $\mathrm{O}_{3}$ may be recovering, the magnitude and sign of stratospheric $\mathrm{O}_{3}$ trends over multi-decadal timescales in the midstratosphere strongly depends on geographical location. It is important to understand the causes of this geographical variation.

Several studies of satellite data show the variability in $\mathrm{O}_{3}$ trends depending upon the exact time frame and geographical location. Kyrölä et al. (2013), using measurements from the Stratospheric Aerosol and Gas Experiment (SAGE) from 1984 to 1997, show a general decrease in $\mathrm{O}_{3}$ that is statistically significant over much of the stratosphere and is particularly large in the mid-latitude upper stratosphere. However, they also show an increase in equatorial $\mathrm{O}_{3}$ (albeit not statistically significant) in the $30-35 \mathrm{~km}$ region.

There are a number of studies covering later years, all of which show a variation in $\mathrm{O}_{3}$ that differs dramatically from that of the 1984-1997 SAGE data. Nedoluha et al. (2015) studied $\mathrm{O}_{3}$ over the period 1991-2005, when Halogen Occultation Experiment (HALOE) measurements are available, and found a strong decrease in mid-stratospheric $\mathrm{O}_{3}$ in the tropics over this period. Kyrölä et al. (2013) also exam- 
ined the period 1997-2011, showing a general increase in $\mathrm{O}_{3}$ from SAGE and Global Ozone Monitoring by Occultation of Stars (GOMOS) measurements, but a statistically significant decrease near $30 \mathrm{~km}$ in the tropics. Measurements from the Scanning Imaging Absorption Spectrometer for Atmospheric Chartography (SCHIAMACHY) instrument for the period 2002-2012, reported by Gebhardt et al. (2014), showed a pattern similar to the 1997-2011 pattern reported by Kyrölä et al. (2013) (i.e., a strong, statistically significant decrease in tropical $\mathrm{O}_{3}$ in the $30-35 \mathrm{~km}$ region while most of the middle atmosphere shows a slight increase in $\mathrm{O}_{3}$ ). Eckert et al. (2014), using Michelson Interferometer for Passive Atmospheric Sounding (MIPAS) data from 2002 to 2012, also showed a general increase in $\mathrm{O}_{3}$ in most regions, especially in the Southern Hemisphere mid-latitudes near $\sim 20 \mathrm{hPa}$, but found statistically significant negative trends in the tropics from $\sim 25 \mathrm{hPa}$ to $5 \mathrm{hPa}$. Finally, Nedoluha et al. (2015) showed that from 2004 to 2013, Aura Microwave Limb Sounder (MLS) measurements showed a strong decrease in mid-stratospheric $\mathrm{O}_{3}$ in the tropics. Nedoluha et al. (2015) also showed, based on changes in $\mathrm{N}_{2} \mathrm{O}$ measured by MLS and $\mathrm{NO}_{x}$ measured by HALOE, that the decadal-scale changes in equatorial $\mathrm{O}_{3}$ of the magnitude observed could best be understood as being caused by dynamical variations. The goal of this paper is to better understand how variations in mid-stratospheric $\mathrm{O}_{3}$ over Lauder are affected by large scale dynamical variations. We will examine in detail two particular variations in $\mathrm{O}_{3}$ : a monthly anomaly in 2001 and a 4-year anomaly from 2009 to 2013. The 4-year anomaly, when analyzed from the beginning of the Aura MLS time series, results in a positive linear $\mathrm{O}_{3}$ trend in the mid-stratosphere over Lauder, in the opposite sense to the trend over this time period in the tropics. An improved understanding of how dynamical variations affect mid-stratospheric $\mathrm{O}_{3}$ variations at this southern mid-latitude site is important for interpreting measurements from midlatitude sites in terms of long-term global $\mathrm{O}_{3}$ change.

This paper is organized as follows. Section 2 describes the ground-based and satellite measurements. Section 3 examines the MOPI1 $\mathrm{O}_{3}$ time series, focusing on the unusual anomalies in 2001 and 2009-2013. Section 4 examines MOPI1 $\mathrm{O}_{3}$ in the context of global $\mathrm{O}_{3}$ and $\mathrm{N}_{2} \mathrm{O}$ variations, and in Sect. 5 we summarize the most prominent anomalies in our data set along with our suggested explanations.

\section{Measurements}

The Microwave Ozone Profiling Instrument (MOPI1) instrument has been making measurements of stratospheric $\mathrm{O}_{3}$ from the Network for the Detection of Atmospheric Composition Change (NDACC) station at Lauder, New Zealand $\left(45.0^{\circ} \mathrm{S}, 169.7^{\circ} \mathrm{E}\right)$ since 1992 . With the exception of repairs, the instrument has been essentially unchanged during this entire period. Both this MOPI1 instrument and the similar
MOPI2 instrument deployed at Mauna Loa, Hawaii, since 1995 , have been used as a ground-based reference for a number of satellite instruments. Satellite measurements can provide a global perspective for the MOPI measurements, and we will use measurements from Aura MLS to provide such a global perspective for MOPI ozone variations since 2004. Here we present a brief description of both the ground-based microwave and satellite measurement techniques.

\subsection{Ground-based microwave measurements}

Each MOPI instrument uses a heterodyne receiver coupled to a 120-channel filter spectrometer to measure the line emission spectrum produced by a thermally excited, purely rotational ozone transition at $110.836 \mathrm{GHz}(2.7 \mathrm{~mm}$ wavelength). The spectral intensities and measurements of the tropospheric thermal emission are calibrated with black body sources at ambient and liquid nitrogen temperatures. The tropospheric opacity is calculated from hourly emission measurements. The experimental technique was described in Parrish et al. (1992), and technical details on the instrument used for this work are given in Parrish (1994). MOPI measurements have been employed in several validation and trend studies (e.g., Boyd et al., 2007; Steinbrecht et al., 2009).

MOPI observations are made continuously, and spectra associated with large or highly variable tropospheric opacity are discarded from further analysis. This technique allows measurements in weather ranging from clear sky to some overcast conditions. The standard MOPI retrieval product, which will be used here, provides up to four retrievals per day. Spectral scans are recorded over $\sim 20 \mathrm{~min}$ intervals, and those scans that are made in suitable weather conditions are averaged over four $6 \mathrm{~h}$ periods starting at local midnight. The diurnal variations in the $\mathrm{O}_{3}$ measurements from the MOPI2 instrument at Mauna Loa (using a $1 \mathrm{~h}$ retrieval product) have been validated and compared to the Goddard Earth Observing System Chemistry Climate Model (GEOSCCM) $\mathrm{O}_{3}$ (Parrish et al., 2014), and measurements and model mixing ratios, compared in $2-3 \mathrm{~km}$ altitude layers from 20 to $65 \mathrm{~km}$, generally agree to better than $1.5 \%$ of the midnight value. For this study we make use of three of the four daily retrievals, and do not include the daytime afternoon measurements (i.e., 12:00 18:00 local time). This selection has been made because, at Lauder, these measurements show a slightly anomalous vertical profile in the mid-stratosphere, with values at $10 \mathrm{hPa}$ lower by $\sim 3 \%$ than at other times of the day. We believe that these variations may be caused by the strong thermal cycles in the building housing the instrument, especially in the afternoon.

In Fig. 1, we show a typical spectrum and $\mathrm{O}_{3}$ profile retrieval from the MOPI1 instrument. As described in Parrish et al. (1992), the measurement shown is obtained using a switching technique (Parrish et al., 1988) so that the spectrum used in the retrievals is the difference between measurements being made at a low elevation angle (typically be- 

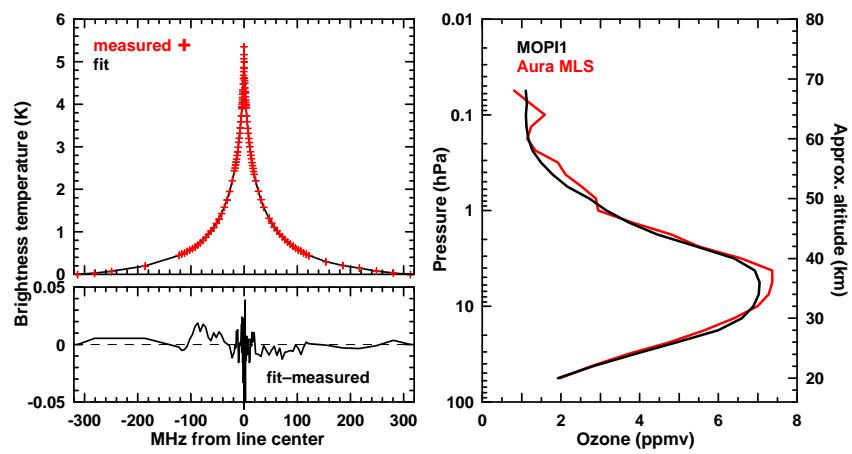

Figure 1. Top left: the spectrum centered at $110.836 \mathrm{GHz}$ as measured by MOPI1 from Lauder over $3 \mathrm{~h}$ on 11 March 2014 (red crosses), and the model fit to this spectrum (black line). Bottom left: the residual difference between the measured and modeled spectrum. Right: the retrieved $\mathrm{O}_{3}$ profile from MOPI1 (black) and from a coincident Aura MLS measurement (red).

tween 15 and $23^{\circ}$ ), and measurements made near the zenith through an attenuating sheet of plexiglass. The low elevation angle measurement is continually adjusted so that the measured temperature in the two positions is approximately balanced, and any remaining slope or offset in this difference spectrum is removed before retrieving the $\mathrm{O}_{3}$ profile. The $\mathrm{O}_{3}$ mixing ratio profiles are retrieved from the difference spectra using an adaptation of the optimal estimation method of Rodgers (1976), discussed in Parrish et al. (1992) and Connor et al. (1995). Error analysis techniques are discussed in the latter paper. The native units of the system are mixing ratio vs. pressure.

In Fig. 2, we show typical averaging kernels for the MOPI1 version 6 retrievals. The vertical resolution of the MOPI1 measurements is $\sim 7-8 \mathrm{~km}$ (FWHM) at $10 \mathrm{hPa}$, slightly coarser than at Mauna Loa, where the MOPI2 resolution at the $10 \mathrm{hPa}$ pressure level is $\sim 6 \mathrm{~km}$. The MOPI retrievals have a measurement contribution of near $100 \%$ at $10 \mathrm{hPa}$, as defined by the technique of Connor et al. (1995).

\subsection{Satellite measurements}

We compare MOPI $\mathrm{O}_{3}$ measurements with observations from three satellites that provide coincident measurements. Two of these are solar occultation instruments, which make $\sim 15$ sunrise and $\sim 15$ sunset high vertical resolution $(\sim 1 \mathrm{~km})$ profile measurements each day, generally at different latitudes, with the latitude bands varying differently over the course of the season depending on the satellite orbit. The majority of MOPI-satellite comparisons come from Aura MLS, which provides measurements over all latitudes between $82^{\circ} \mathrm{S}$ and $82^{\circ} \mathrm{N}$ on a daily basis.

The SAGE II instrument was launched in October 1984 aboard the Earth Radiation Budget Satellite, and continued making measurements through August 2005. It consisted of a seven-channel solar photometer using ultraviolet and vis-

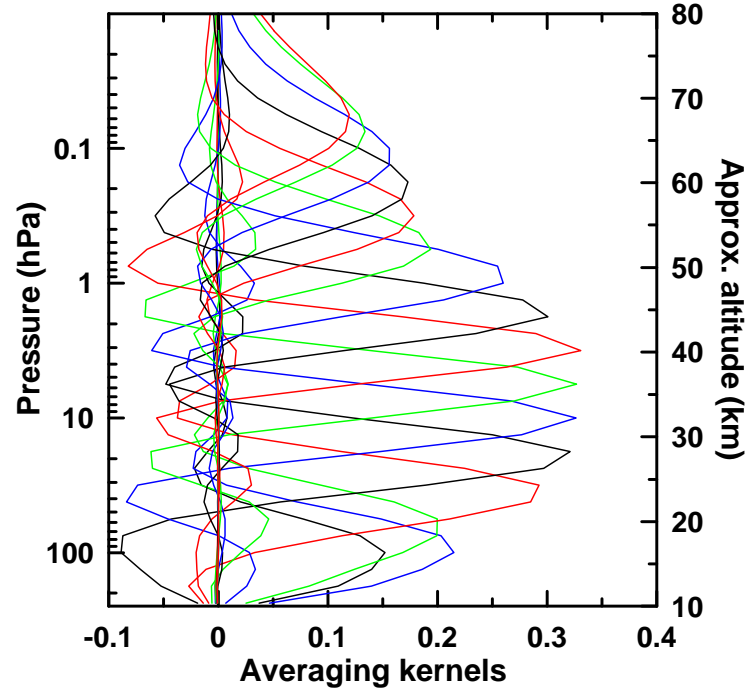

Figure 2. Typical averaging kernels for the MOPI1 instrument based on $6 \mathrm{~h}$ of spectral integration. Averaging kernels are shown for every second level, with the averaging kernels in blue shown at $100,10,1$, and $0.1 \mathrm{hPa}$.

ible channels between 0.38 and $1.0 \mu \mathrm{m}$ in solar occultation mode to retrieve atmospheric profiles of ozone, water vapor, nitrogen dioxide and aerosol extinction. Measurements were made over a latitude range from $80^{\circ} \mathrm{S}$ to $80^{\circ} \mathrm{N}$. The measurements are retrieved as ozone number density as a function of altitude, but are also provided as ozone mixing ratio as a function of pressure. The version 6.1 data are described in Wang et al. (2002).

The v7.00 data set (Damadeo et al., 2013), released in December 2012, is used in this analysis. This latest processing version implements an algorithm that is consistent across all SAGE missions. The most significant change in the new version is that, whereas the previous SAGE retrievals made use of the meteorological profiles from the Climate Prediction Center (CPC) NCEP analysis, the new retrievals make use of the Modern Era Retrospective-Analysis for Research and Applications (MERRA) reanalysis. Retrievals using the meteorological profiles from the MERRA reanalysis show significantly different $\mathrm{O}_{3}$ mixing ratios as a function of pressure in the upper stratosphere and mesosphere (pressures below $\sim 4 \mathrm{hPa}$ ). For the pressure levels of interest for this study, however, the differences between the v6.1 and v7.00 SAGE $\mathrm{O}_{3}$ retrievals are insignificant.

HALOE solar occultation measurements of $\mathrm{O}_{3}$ are available from 1991 to 2005 . The latitude bands drifted daily so that near global latitudinal coverage was provided in both sunrise and sunset modes five times over the course of a year. The trends in the HALOE $\mathrm{O}_{3}$ measurements have been compared against SAGE II (Nazaryan et al., 2005), and differences have been found to be on the order of less than $0.3 \%$ 

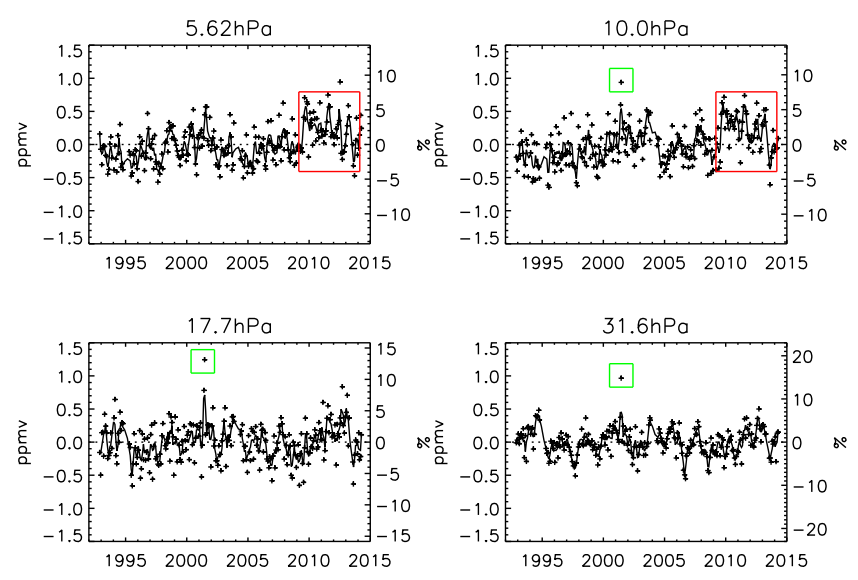

Figure 3. Crosses show monthly ozone anomalies from the MOPI1 measurements. The line shows a 3-point smoothing of the data. Boxes indicate periods of particular interest (see text).

per year in a majority of latitude bands at $25,35,45$, and $55 \mathrm{~km}$.

Aura MLS measurements of $\mathrm{O}_{3}$ and $\mathrm{N}_{2} \mathrm{O}$ are available since 2004. The stratospheric $\mathrm{O}_{3}$ product has been validated by Froidevaux et al. (2008). The vertical resolution of the MLS $\mathrm{O}_{3}$ measurements at $10 \mathrm{hPa}$ is $\sim 3 \mathrm{~km}$. The $\mathrm{N}_{2} \mathrm{O}$ measurements have been validated by Lambert et al. (2007) and have a vertical resolution of $\sim 4 \mathrm{~km}$. Upper Atmosphere Research Satellite (UARS) MLS measurements of $\mathrm{O}_{3}$ are available from 1991 to 1999, and were validated by Froidevaux et al. (1996) for the v2.2 retrievals and by Livesey et al. (2003) for the $\mathrm{v} 5$ retrievals.

\section{The MOPI $\mathrm{O}_{3}$ time series}

In Fig. 3, we show the monthly anomalies at selected pressure levels for the entire MOPI1 data record. The anomalies are calculated by first fitting the data with a sinusoidal seasonal cycle (including annual and semi-annual terms) and then subtracting this seasonal cycle from the data. There are two interesting features that particularly stand out. The first is the large positive anomaly that occurs in June 2001 at 31.6, 17.7, and 10.0 hPa (green boxes). The second, much longer-term feature, is the positive anomaly at 10.0 and $5.6 \mathrm{hPa}$ from August 2009 through July 2013 (red boxes). During this period the mean monthly $\mathrm{O}_{3}$ anomaly at $10 \mathrm{hPa}$ is 0.32 ppmv, only 7 of the 47 measurement months show a negative anomaly, and the 3 month smoothing never shows a negative anomaly. This period ends with a sharp drop in $\mathrm{O}_{3}$ in August 2013.

\subsection{Unusually high mid-stratospheric $\mathrm{O}_{3}$ in June 2001}

Since there are no MLS measurements available to document the global variation in $\mathrm{O}_{3}$ during June 2001, we use Tracer Equivalent Latitude (TrEL) simulations in order to better un-

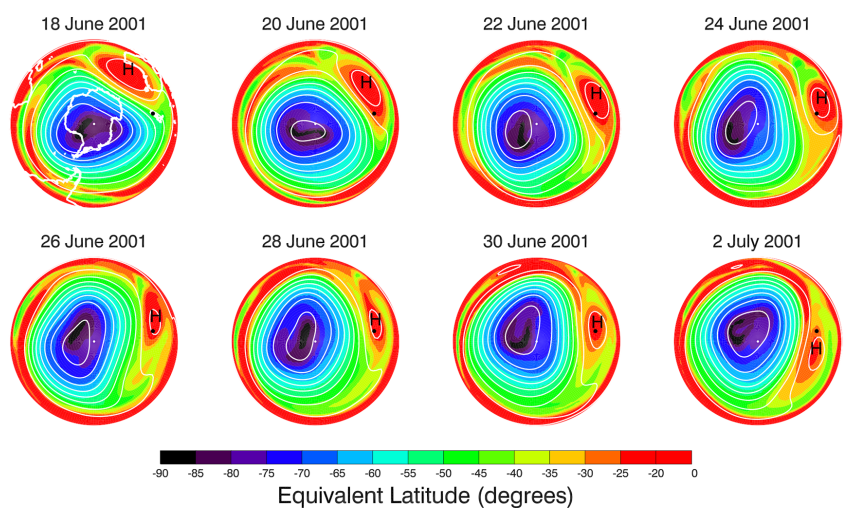

Figure 4. The tracer equivalent latitude (see text) for the Southern Hemisphere at $650 \mathrm{~K}$. The location of Lauder $\left(45^{\circ} \mathrm{S}, 169.7^{\circ} \mathrm{E}\right)$ is indicated by a black dot. White contours are $650 \mathrm{~K}$ streamlines at constant intervals. The black " $\mathrm{H}$ " indicates the location of strong anticyclonic circulation.

derstand the June 2001 anomaly over Lauder. TrEL is determined from isentropic passive tracer advection calculations on the sphere as described by Allen and Nakamura (2003). The tracer mixing ratio is converted to an equivalent latitude by matching the area enclosed by tracer contours to that enclosed by an equivalent latitude line. Specific details of the TrEL calculation used for this paper, based on MERRA winds, are provided by Allen et al. (2012). The average TrEL in June 2001 over Lauder on potential temperatures surfaces from 550 to $850 \mathrm{~K}(\sim 35$ to $10 \mathrm{hPa}$ ) was the highest (i.e., most equatorward TrEL) June average observed throughout the 36-year period from 1979 to 2014 . At $650 \mathrm{~K}$ the mean TrEL value at Lauder in June 2001 was $\sim 31^{\circ} \mathrm{S}$, indicating unusually tropical air relative to the latitude of the site.

From $\sim 30$ to $\sim 3 \mathrm{hPa}, \mathrm{O}_{3}$ generally increases from pole to equator throughout the year; hence the unusually high (equatorward) TrEL is associated with high $\mathrm{O}_{3}$. We calculated the climatological monthly $\mathrm{O}_{3}$ latitudinal gradient from 45 to $35^{\circ} \mathrm{S}$ from the MLS measurements, and found that from 20 to $10 \mathrm{hPa}$, this gradient peaks during the months of March-June. Hence $\mathrm{O}_{3}$ mixing ratios measured over Lauder are particularly sensitive to changes in TrEL during these months. Thus the unusually high $\mathrm{O}_{3}$ anomaly in June 2001 is likely the result of an unusual amount of equatorward air over Lauder at a time when $\mathrm{O}_{3}$ variations are particularly sensitive to such transport.

To better explain the dynamics that caused this unusually high TrEL (and hence $\mathrm{O}_{3}$ ) over Lauder in June 2001 we show, in Fig. 4, the TrEL at $650 \mathrm{~K}(\sim 20 \mathrm{hPa})$ for the entire Southern Hemisphere from 18 June to 2 July 2001. Low TrEL occurs throughout the polar vortex, also identified by streamlines (white contours) circling the pole. A strong anticyclone, identified by closed streamlines and elevated TrEL (marked with black "H"), moves eastward from 18 to 22 June, before remaining relatively stationary for the next 


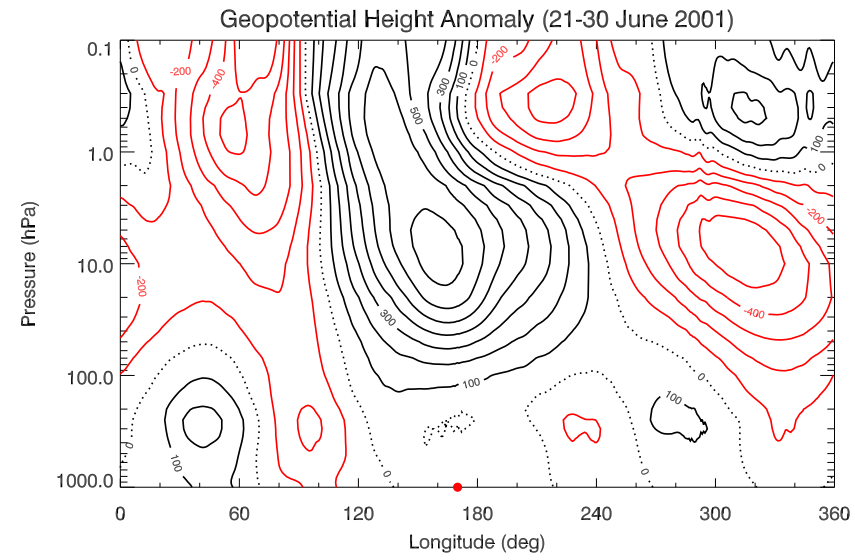

Figure 5. The MERRA geopotential height anomaly, in $100 \mathrm{~m}$ increments, calculated for the period $21-30$ June 2001 , at $45^{\circ} \mathrm{S}$. The longitude of Lauder is indicated by the red dot. Positive (negative) anomalies are identified by solid black (red) contours, while the black dotted line indicates zero anomaly.

8 days. This is an unusually strong "blocking" type pattern that kept high TrEL/high $\mathrm{O}_{3}$ air over Lauder. Figure 5 shows the vertical structure of this feature at $45^{\circ} \mathrm{S}$, identified by zonal anomalies of geopotential height over a range of pressure surfaces from 1000 to $0.1 \mathrm{hPa}$. Elevated values extend from the tropopause $(\sim 200 \mathrm{hPa})$ into the lower mesosphere, tilting westward and narrowing with height. The anomaly peaks at $\sim 10 \mathrm{hPa}$, with a longitudinal extent of $\sim 120^{\circ}$. While this quasi-stationary stratospheric "Australian high" signature is known to occur in the SH spring (Harvey et al., 2002), this is the largest and most persistent episode observed in June in the 36-year TrEL simulation.

\subsection{Unusually high mid-stratospheric $\mathrm{O}_{3}$ from August 2009 through July 2013}

The 4 years of elevated $\mathrm{O}_{3}$ (2009-2013) occurred during the period when coincident Aura MLS measurements are available. Aura MLS overpasses occur near 01:15 and 14:30 local solar time at the latitude of Lauder. Since we are not using the MOPI1 measurements from 12:00 to 18:00, only the 01:15 overpasses are used. For comparison with MOPI1, we choose a longitude coincidence criterion of $\pm 6^{\circ}$, which generally includes two daily 01:15 MLS overpasses. The monthly averages at $10 \mathrm{hPa}$ from 2004 to 2014 are compared in Fig. 6. In Fig. 6, we show MLS measurements both with and without convolution with MOPI averaging kernels. As the difference is small, all other satellite measurements are shown without convolution. The MLS measurements show very good agreement with the MOPI measurements over the entire period, and both instruments show the large $\mathrm{O}_{3}$ increase in mid-2009 and the large decrease in mid-2013. In mid-2009, mixing ratios increased from values near the lowest observed during the Lauder winter over this 10 -year period, to values at, or

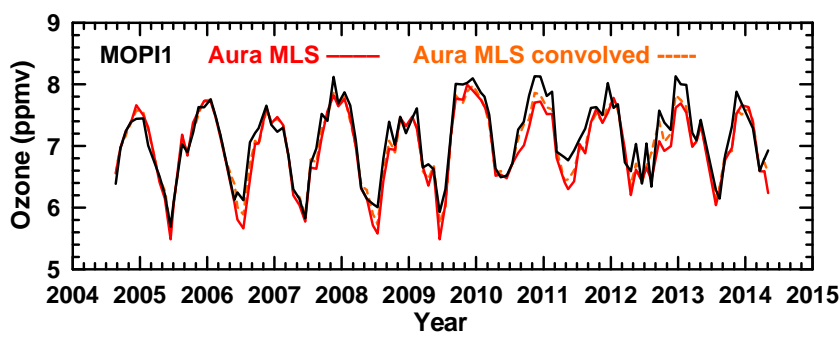

Figure 6. Monthly ozone averages for MOPI1 (black), Aura MLS (red), and Aura MLS convolved with the MOPI averaging kernels (dashed orange) measurement pairs at $10 \mathrm{hPa}$. Measurements are shown when there is an MLS measurement taken within $\pm 1^{\circ}$ latitude and $\pm 6^{\circ}$ longitude within $6 \mathrm{~h}$ of a MOPI measurement.

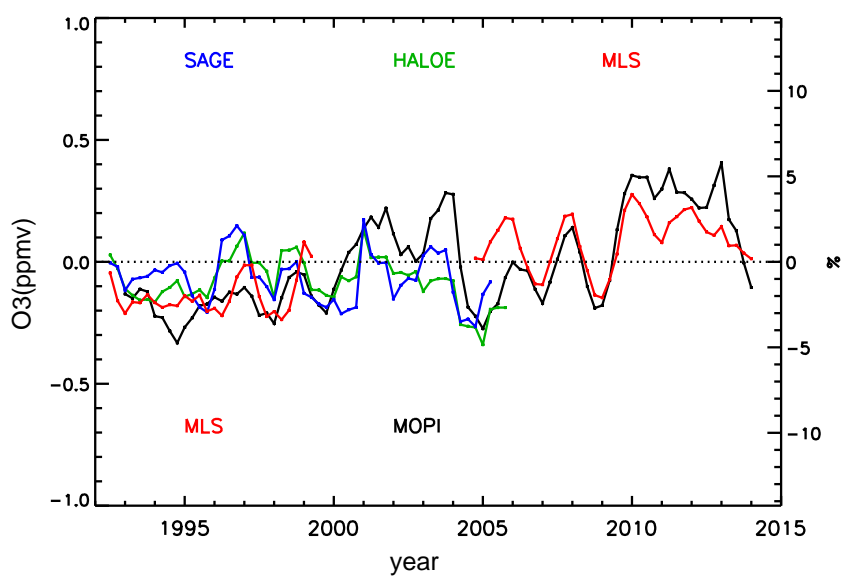

Figure 7. Annual average ozone anomalies at $10 \mathrm{hPa}(30 \mathrm{~km}$ for SAGE II) shown 4-times annually (with annual averages for each instrument taken from January to December, April to March, July to June, and October to September). Results are shown for SAGE II (blue), HALOE (green), UARS and Aura MLS (both red), and MOPI1 (black). Satellite measurements (latitudinal averages from 40 to $50^{\circ} \mathrm{S}$ ) have been offset so that the average ozone matches that of MOPI1 during the period of coincidence.

near, the highest observed in a Lauder summer. There was a month-long gap in the MOPI1 measurements in July 2013, but the observed drop in the coincident MLS measurements is very similar to that of the MOPI1 measurements between June and August 2013. Both instruments show that, in $\mathrm{Au}-$ gust 2013, the $\mathrm{O}_{3}$ values were the lowest since 2009 .

The unusual nature of the 2009-2013 period is even more clearly emphasized in Fig. 7, which shows annual average anomalies from MOPI and from four satellite instruments that measured $\mathrm{O}_{3}$ over extended periods since the early 1990s. All of the measurements shown in Fig. 7 are provided on their native grid. For the SAGE II measurements the native grid is altitude, and results are shown at $30 \mathrm{~km}$. For HALOE, UARS and Aura MLS, and MOPI we show results at a $10 \mathrm{hPa}$. Note that, with the exception of the MOPI measurements, the $\mathrm{O}_{3}$ anomalies shown in Fig. 7 are zonally 
averaged. Since only the MOPI1 measurements are available throughout the entire time period, all of the satellite measurements have been offset so that the average ozone matches that of MOPI1 during the period of coincidence. We note that there is an increase of $\sim 4 \%$ in the MOPI measurements relative to both the locally coincident and the zonally averaged and convolved Aura MLS (shown in Fig. 6), which occurs primarily near the beginning of the Aura MLS time series. Since Fig. 7 shows annual averages it helps to emphasize the Quasi-Biennial Oscillation (QBO). The annualaverage MOPI measurements show local minima in 1997, 1999, 2002, 2004, late 2006/early 2007, and late 2008/early 2009. Following the minimum in late 2008/early 2009 the $\mathrm{O}_{3}$ rises and remains well above the long-term average until 2013.

\section{$4 \quad \mathrm{O}_{3}$ and $\mathrm{N}_{2} \mathrm{O}$ at Lauder and at the Equator}

\subsection{Monthly $\mathrm{O}_{3}$ anomaly correlations}

To better understand the global implications of the observed $\mathrm{O}_{3}$ variations over Lauder, we investigated how the variations in $\mathrm{O}_{3}$ observed over Lauder compare globally with changes in $\mathrm{MLS} \mathrm{O}_{3}$. We first calculated monthly averaged $\mathrm{O}_{3}$ at each MLS pressure level from 50 to $1 \mathrm{hPa}$ in $2^{\circ}$ latitude bins for 10 years of MLS data (2004-2014). We then calculated a climatological (i.e., 10 year) average for each calendar month. Using this climatology, we calculated an anomaly for each month of the 10-year series as a function of latitude and pressure. A similar monthly anomaly time series was calculated for the MOPI ozone at $10 \mathrm{hPa}$. Correlation coefficients were calculated between the $10 \mathrm{hPa}$ MOPI anomalies and the MLS anomalies at different pressures and latitudes, using months where both MLS and MOPI measurements were available.

Figure 8 shows the correlation coefficient $(r)$ as a function of pressure and latitude. The strongest correlation occurs slightly equatorward of Lauder and at a slightly higher pressure level. This is likely due to differences in instrumental errors, vertical resolution, and because the MOPI1 measurement is for local conditions near Lauder and not a zonal average. At the equator and $10 \mathrm{hPa}$ there is a strong anticorrelation $(r<-0.5)$ between MOPI1 and MLS (the correlation between $10 \mathrm{hPa}$ MLS $\mathrm{O}_{3}$ at $45^{\circ} \mathrm{S}$ and the equator is similar). There is also a weaker anti-correlation between MOPI1 and MLS $\mathrm{O}_{3}$ at $\sim 20-45^{\circ} \mathrm{N}$ below $10 \mathrm{hPa}$.

The geographical correlations seen in Fig. 8 are similar to those discovered by Randel and Wu (1996), who used singular value decomposition (SVD) analysis to study the relationship between QBO zonal winds and global SAGE $\mathrm{O}_{3}$ anomalies. The second mode of their analysis (SVD2; which explains $25 \%$ of the overall covariance) shows an anticorrelation between $10 \mathrm{hPa} \mathrm{O}_{3}$ at southern mid-latitudes and at the equator. It also shows a much weaker anti-correlation

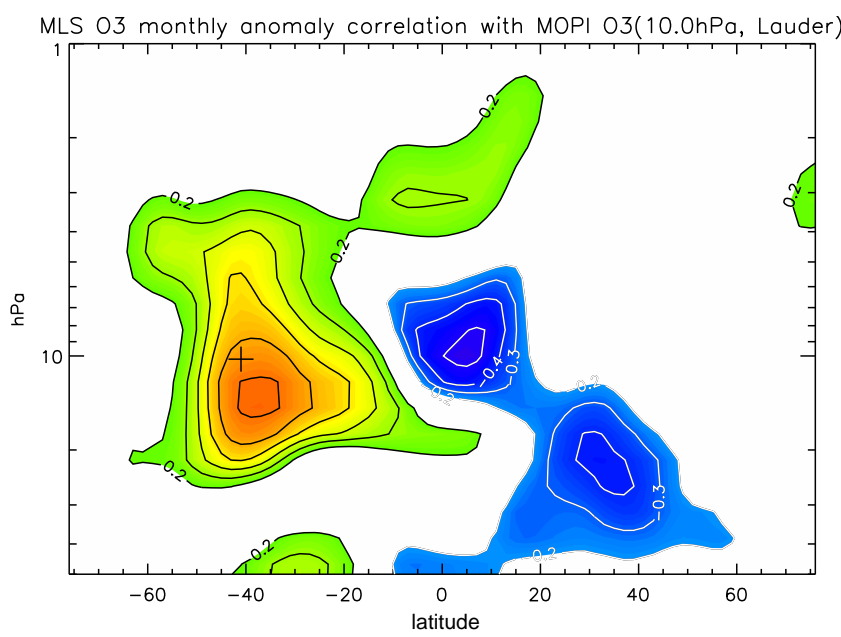

Figure 8. The correlation coefficient of the monthly MLS $\mathrm{O}_{3}$ anomalies with the monthly anomalies of the MOPI $\mathrm{O}_{3}$ measurements at $10 \mathrm{hPa}$. The cross represents the latitude of Lauder at $10 \mathrm{hPa}$. Contour lines are shown for $r= \pm 0.2,0.3,0.4,0.5,0.6$, and 0.7 .

between $10 \mathrm{hPa} \mathrm{O}_{3}$ at southern mid-latitudes and $\mathrm{O}_{3}$ at northern mid-latitudes at slightly higher pressures.

Of course the temporal correlations shown in Fig. 8 give no indication of the time period over which the correlation is taking place (by using anomalies we have eliminated only the seasonal cycle), and could, e.g., represent QBOlike variations, solar-cycle-driven variations, or decadalscale changes. What Fig. 8 certainly does emphasize is that the anomalies over Lauder at $10 \mathrm{hPa}$ during the period 20042014 are not, predominantly, driven by a decadal-scale global trend.

\subsection{Links between $\mathrm{O}_{3}$ and $\mathrm{N}_{2} \mathrm{O}$}

Nedoluha et al. (2015) showed that $\mathrm{O}_{3}$ variations at the equator are very strongly positively correlated to variations in $\mathrm{N}_{2} \mathrm{O}$. This relationship could best be understood as resulting from dynamical variations. Using a 2-D chemical transport model, Nedoluha et al. (2015) showed that slower ascent resulted in more $\mathrm{N}_{2} \mathrm{O}$ being photodissociated and oxidized to produce $\mathrm{NO}_{x}$ (while reducing $\mathrm{N}_{2} \mathrm{O}$ ), and the increased $\mathrm{NO}_{x}$ destroyed more ozone, resulting in a positive correlation between $\mathrm{O}_{3}$ and $\mathrm{N}_{2} \mathrm{O}$. Such a relationship has been previously deduced from changes in HALOE measurements of $\mathrm{NO}_{2}$ at $\sim 10 \mathrm{hPa}$ from 1993 to 1997, where the change in $\mathrm{NO}_{2}$ was shown to be consistent with a decrease in upward transport (Nedoluha et al., 1998).

In Fig. 9, we show monthly average anomalies for $\mathrm{O}_{3}$ and $\mathrm{N}_{2} \mathrm{O}$ from Aura MLS and MOPI at $10 \mathrm{hPa}$. The variations in both $\mathrm{O}_{3}$ and $\mathrm{N}_{2} \mathrm{O}$ from $5^{\circ} \mathrm{S}$ to $5^{\circ} \mathrm{N}$ (Fig. 9, right) show a clear, and similar, $\mathrm{QBO}$ signature. The connection between the QBO signal in $\mathrm{O}_{3}$ and $\mathrm{NO}_{y}$ (which is affected by $\mathrm{N}_{2} \mathrm{O}$ ) was recognized in SAGE II data by Chipperfield et al. (1994), 

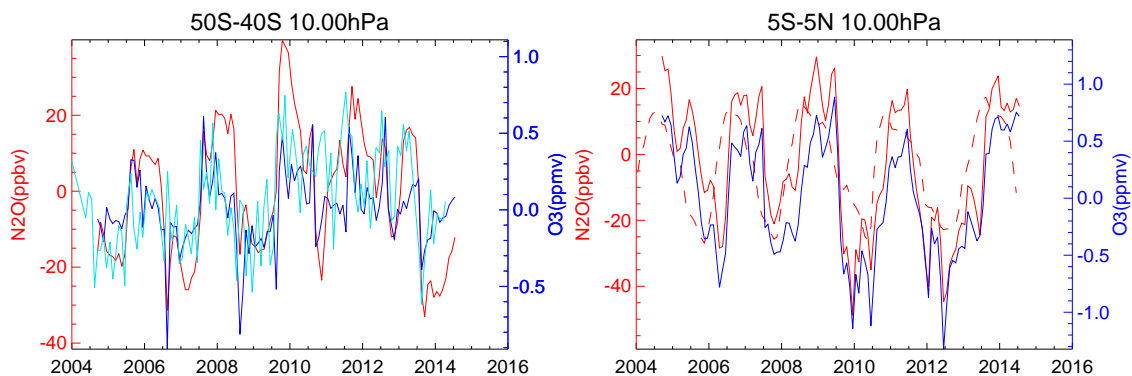

Figure 9. Monthly average anomalies for $\mathrm{N}_{2} \mathrm{O}$ (red) and $\mathrm{O}_{3}$ (blue) as measured by MLS at $10 \mathrm{hPa}$ within $5^{\circ}$ of the Lauder latitude (45 $\mathrm{S}$ ) (left) and within $5^{\circ}$ of the equator (right). The left hand plot also shows the monthly average $\mathrm{O}_{3}$ anomalies (based on the 2004-2014 averages) for MOPI (cyan). The right hand plot also shows (dashed red line) the $30 \mathrm{hPa}$ QBO index in $\mathrm{m} \mathrm{s}^{-1}$, using the same numerical scale as the $\mathrm{N}_{2} \mathrm{O}$ in ppbv.
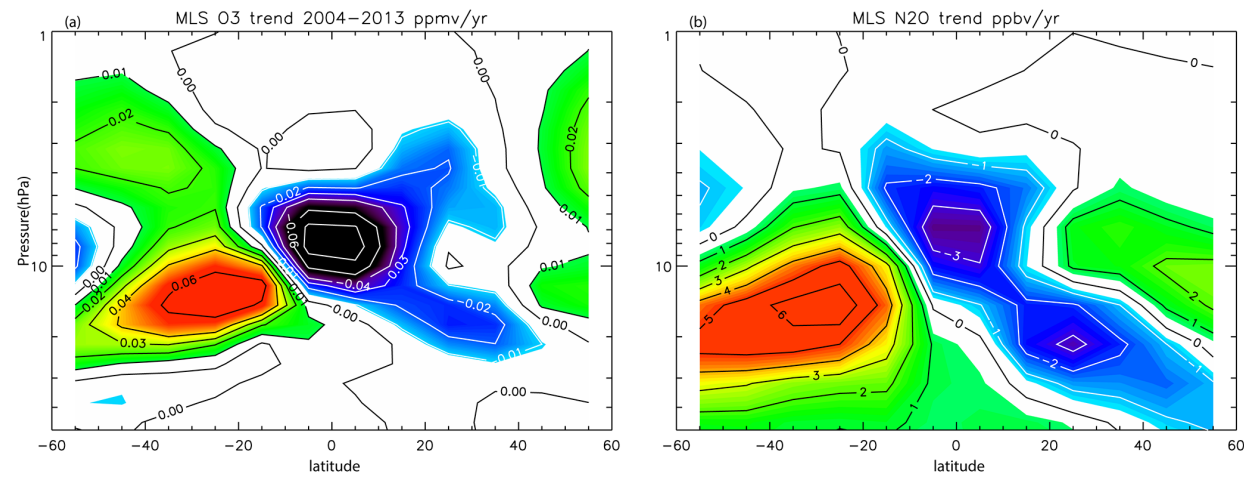

Figure 10. Linear trend fits to $\mathrm{MLS}_{3}$ and $\mathrm{N}_{2} \mathrm{O}$ measurements from August 2004 through May 2013. Contour lines for $\mathrm{O}_{3}$ are shown at

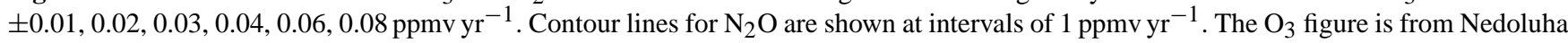
et al. (2015).

who pointed out that it was the result of QBO modulation of the vertical advection, with faster ascent resulting in larger $\mathrm{O}_{3}$ mixing ratios in the mid-stratosphere.

In addition to $\mathrm{O}_{3}$ and $\mathrm{N}_{2} \mathrm{O}$, Fig. 9 shows the zonally averaged $30 \mathrm{hPa}$ QBO winds over the equator from the Climate Data Assimilation System (from www.cpc.ncep.noaa.gov). The $10 \mathrm{hPa}$ equatorial $\mathrm{O}_{3}$ and $\mathrm{N}_{2} \mathrm{O}$ anomalies show a slight phase lag relative to the $30 \mathrm{hPa} \mathrm{QBO}$ wind anomaly, but the generally positive correlation between this $30 \mathrm{hPa}$ wind anomaly and $\mathrm{O}_{3}$ and $\mathrm{N}_{2} \mathrm{O}$ mixing ratios suggests that an anomalously fast ascent rate near $10 \mathrm{hPa}$ is associated with westerly (positive) winds at $30 \mathrm{hPa}$.

Figure 9 also shows that in 2006, 2008, 2010, and 2013 there are sharp increases in $\mathrm{O}_{3}$ and $\mathrm{N}_{2} \mathrm{O}$ from $5^{\circ} \mathrm{S}$ to $5^{\circ} \mathrm{N}$ near the middle of the year, while in 2007, 2009, and 2011 there are sharp decreases. Following these sharp changes the equatorial anomaly often remains high (or low) until the next June/July period. Thus the variation is often nearly biennial except for the absence of a change in sign for the $\mathrm{O}_{3}$ and $\mathrm{N}_{2} \mathrm{O}$ anomalies from $5^{\circ} \mathrm{S}$ to $5^{\circ} \mathrm{N}$ in June/July 2012.

While the variation shown in Fig. 9 seems to be primarily nearly biennial, the period from 2009 to 2013 shows lower average equatorial $\mathrm{O}_{3}$ and $\mathrm{N}_{2} \mathrm{O}$ mixing ratios than are ob- served from 2004 to 2008 , as is apparent in the annual averages shown in Fig. 7. Figure 9 shows that the $5^{\circ} \mathrm{S}$ to $5^{\circ} \mathrm{N} \mathrm{O}_{3}$ and $\mathrm{N}_{2} \mathrm{O}$ mixing ratios have both lower maxima and lower minima at a similar phase of the QBO. While these equatorial $\mathrm{N}_{2} \mathrm{O}$ and $\mathrm{O}_{3}$ anomalies are correlated with the phase of the QBO wind anomalies, it is not clear whether or not the unusually low $\mathrm{O}_{3}$ and $\mathrm{N}_{2} \mathrm{O}$ mixing ratios in 2009-2013 are associated with unusual QBO wind anomalies.

There are some peculiarities in the $\mathrm{QBO}$ winds during the 2009-2013 period. For instance, the westerly wind anomalies in 2010 are weaker than the other four cycles during this period $\left(16.0 \mathrm{~m} \mathrm{~s}^{-1}\right.$ in August 2010 is the lowest maximum since 1992). The easterly $30 \mathrm{hPa}$ wind anomalies in 2009/2010 are unusually strong for $\sim 3$ months before an unusually fast transition back to westerly winds, while the $21.4 \mathrm{~m} \mathrm{~s}^{-1}$ maximum easterly wind anomaly in 2012 is the weakest over the four cycles shown. The $30 \mathrm{hPa}$ wind anomalies during the 2008-2013 period persist for slightly longer than usual. The winds switched from easterly to westerly in March 2008, August 2010, and March 2013, producing QBOs of length 29 and 31 months, respectively.

The $10 \mathrm{hPa} \mathrm{O}_{3}$ and $\mathrm{N}_{2} \mathrm{O}$ anomalies at 40 to $50^{\circ} \mathrm{S}$ (Fig. 9, left) are not as strongly correlated as at the equator (see 
Fig. 4, Nedoluha et al., 2015), but nonetheless there is clearly a positive correlation between the anomalies of these two species. Not unexpectedly, given the correlations shown in Fig. 8, these southern mid-latitude anomalies show variations that are usually opposite to those seen at the equator. Most clearly the sharp changes in June/July are anti-correlated with those near the equator. Figure 9 shows that, like the $\mathrm{O}_{3}$ values that have been shown previously, the $\mathrm{N}_{2} \mathrm{O}$ values over latitudes near Lauder are elevated from 2009 to 2013.

The lower stratospheric anomalies in $\mathrm{O}_{3}$ and $\mathrm{N}_{2} \mathrm{O}$ at 40 to $50^{\circ} \mathrm{S}$ are likely to be caused by the variations in the rate at which tropical air with high $\mathrm{N}_{2} \mathrm{O}$ and low $\mathrm{O}_{3}$ air moves into the southern mid-latitudes, relative to the rate at which low $\mathrm{N}_{2} \mathrm{O}$ and high $\mathrm{O}_{3}$ air descends into this region. The same tropical $30 \mathrm{hPa}$ westerly winds which are associated with the increased ascent rate in the tropics seem to be correlated with a decrease in transport from the tropics into the Southern Hemisphere, resulting in an anti-correlation between $\mathrm{N}_{2} \mathrm{O}$ (and hence $\mathrm{O}_{3}$ ) anomalies at the tropics and the southern mid-latitudes.

\subsection{Decadal changes in $\mathrm{O}_{3}$ and $\mathrm{N}_{2} \mathrm{O}$}

To provide a global perspective on the 2009-2013 anomalies, we used linear regression to fit the MLS monthly mean data from August 2004 through May 2013 to 8 parameters, including annual and semi-annual sinusoidal terms, the 30 and $50 \mathrm{hPa}$ QBO winds, and a linear trend term. The linear trend terms from these fits are shown in Fig. 10. Based on the monthly MLS data set that was used for the fit, the average $1 \sigma$ uncertainty in the $\mathrm{O}_{3}$ $\left(\mathrm{N}_{2} \mathrm{O}\right)$ trend fit is $0.008 \mathrm{ppmv} \mathrm{yr}^{-1}\left(0.46 \mathrm{ppbv} \mathrm{yr}^{-1}\right)$, and it is $<0.020 \mathrm{ppmv} \mathrm{yr}^{-1}\left(<1.05 \mathrm{ppbv} \mathrm{yr}^{-1}\right)$ everywhere in Fig. 10. The $1 \sigma$ uncertainty in the $\mathrm{O}_{3}\left(\mathrm{~N}_{2} \mathrm{O}\right)$ trend fit at $45^{\circ} \mathrm{S}$ is $<0.011 \mathrm{ppmv} \mathrm{yr}^{-1}\left(<0.76 \mathrm{ppbv} \mathrm{yr}^{-1}\right)$. Since there is no clear correlation between the amplitude of the QBO wind variation and the depth of the $\mathrm{N}_{2} \mathrm{O}$ and $\mathrm{O}_{3}$ changes in 2009-2013, these changes are fit by the linear trend term. The $\mathrm{O}_{3}$ linear trend fit plot (Fig. 10a) has been shown previously in Nedoluha et al. (2015), where it was shown that the decrease observed at $10 \mathrm{hPa}$ near the equator has been occurring for more than 20 years. While a linear trend is clearly a very coarse representation of the MLS data from 2004 to 2013, it does allow us to show the strong global correlations between $\mathrm{N}_{2} \mathrm{O}$ and $\mathrm{O}_{3}$ increases (and decreases) during this time period. While the beginning and ending dates are slightly different, Fig. 10 is qualitatively consistent with the conclusion in Mahieu et al. (2014) that the air in the SH midlatitude lower stratosphere is younger in 2010/2011 than in 2005/2006, while the opposite is true in the NH. Stiller et al. (2012) show an age-of-air trend from 2002 to 2010 which exhibits the same interhemispheric difference over much of the lower stratosphere at mid-latitudes, but they do show older air over the latitude of Lauder above $25 \mathrm{~km}$.

\section{Conclusions}

We have investigated two unusual $\mathrm{O}_{3}$ variations which occurred in the mid-stratosphere over Lauder, New Zealand during the 22 years of ground-based microwave measurements from the site. First, we examined a large positive $\mathrm{O}_{3}$ anomaly that was observed by the MOPI instrument in June 2001. The anomaly was associated with an unusually persistent stratospheric blocking anticyclone that kept air from more equatorial latitudes (with high ozone) over Lauder for much of this month. The very unusual nature of this event was emphasized by comparing the average Tracer Equivalent Latitude (TrEL) in June 2001 over Lauder on potential temperatures surfaces from 550 to $850 \mathrm{~K}(\sim 35$ to $10 \mathrm{hPa})$ with values found in other years. It was found that the TrEL in June 2001 was higher (i.e., more equatorward TrEL) than in any other June throughout the 36-year period 1979-2014.

The second interesting, and much longer-term, feature is the positive $\mathrm{O}_{3}$ anomaly near $\sim 10 \mathrm{hPa}$ which persists over southern mid-latitudes from 2009 to 2013. During this period $\mathrm{N}_{2} \mathrm{O}$ in this region is also unusually high, and the same chemical-dynamical relationship that causes the very strong $\mathrm{N}_{2} \mathrm{O}-\mathrm{O}_{3}$ correlation in the tropics is likely the cause of the high $\mathrm{O}_{3}$. Briefly, $\mathrm{N}_{2} \mathrm{O}$ decreases rapidly both as a function of increasing altitude and increasing distance from the tropics due to photodissociation and oxidation. Thus the high $\mathrm{N}_{2} \mathrm{O}$ at southern mid-latitudes from 2009 to 2013 suggests that air was transported into this region from the tropical lower stratosphere more quickly during this period, thus decreasing the amount of photodissociation and oxidation of $\mathrm{N}_{2} \mathrm{O}$. At the same time, air was being transported more slowly into the tropical $10 \mathrm{hPa}$ region. The mid-2013 decrease in midlatitude $\mathrm{N}_{2} \mathrm{O}$ suggests that air is now again being transported more quickly upwards in the tropics as opposed to being shifted towards southern mid-latitudes, but it remains to be seen whether this is a brief interruption, a halt, or a reversal of a decadal-scale trend.

Acknowledgements. We especially thank M. Kotkamp and A. Thomas for their long-term support of the MOPI instrument at Lauder. This project was funded by NASA under the Upper Atmosphere Research Program, by the Naval Research Laboratory, and by the Office of Naval Research. Work at the Jet Propulsion Laboratory, California Institute of Technology, was carried out under a contract with the National Aeronautics and Space Administration. MLS and HALOE data are available from the NASA Goddard Earth Science Data Information and Services Center (acdisc.gsfc.nasa.gov).

Edited by: T. von Clarmann 


\section{References}

Allen, D. R. and Nakamura, N.: Tracer equivalent latitude: a diagnostic tool for isentropic transport studies, J. Atmos. Sci., 60, 287-304, 2003.

Allen, D. R., Douglass, A. R., Nedoluha, G. E., and Coy, L.: Tracer transport during the Arctic stratospheric final warming based on a 33-year (1979-2011) tracer equivalent latitude simulation, Geophys. Res. Lett., 39, L12801, doi:10.1029/2012GL051930, 2012.

Boyd, I. S., Parrish, A. D., Froidevaux, L., von Clarmann, T., Kyrola, E., Russell III, J. M., and Zawodny, J. M.: Ground-based microwave ozone radiometer measurements compared with AuraMLS v2.2 and other instruments at two Network for Detection of Atmospheric Composition Change sites, J. Geophys. Res., 112, D24S33, doi:10.1029/2007JD008720, 2007.

Chipperfield, M. P., Gray, L. J., Kinnersley, J. S., and Zawodny, J.: A two-dimensional model study of the QBO signal in SAGE II $\mathrm{NO}_{2}$ and $\mathrm{O}_{3}$, Geophys. Res. Lett., 21, 589-592, 1994.

Connor, B. J., Parrish, A., Tsou, J. J., and McCormick, M. P.: Error analysis for the groundbased microwave ozone measurements during STOIC, J. Geophys. Res., 100, 9283-9291, 1995.

Damadeo, R. P., Zawodny, J. M., Thomason, L. W., and Iyer, N.: SAGE version 7.0 algorithm: application to SAGE II, Atmos. Meas. Tech., 6, 3539-3561, doi:10.5194/amt-6-3539-2013, 2013

Eckert, E., von Clarmann, T., Kiefer, M., Stiller, G. P., Lossow, S., Glatthor, N., Degenstein, D. A., Froidevaux, L., GodinBeekmann, S., Leblanc, T., McDermid, S., Pastel, M., Steinbrecht, W., Swart, D. P. J., Walker, K. A., and Bernath, P. F.: Drift-corrected trends and periodic variations in MIPAS IMK/IAA ozone measurements, Atmos. Chem. Phys., 14, 25712589, doi:10.5194/acp-14-2571-2014, 2014.

Froidevaux, L., Read, W. G., Lungu, T. A., Cofield, R. E., Fishbein, E. F., Flower, D. A., Jarnot, R. F., Ridenoure, B. P., Shippony, Z., Waters, J. W., Margitan, J. J., McDermid, I. S., Stachnik, R. A., Peckham, G. E., Braathen, G., Deshler, T., Fishman, J., Holmann, D. J., and Oltmans, S. J.:Validation of UARS Microwave Limb Sounder Ozone Measurements, J. Geophys. Res., 101, 1001710060, 1996.

Froidevaux, L., Jiang, Y. B., Lambert, A., Livesey, N. J., Read, W. G., Waters, J. W., Browell, E. V., Hair, J. W., Avery, M. A., McGee, T. J., Twigg, L. W., Sumnicht, G. K., Jucks, K. W., Margitan, J. J., Sen, B., Stachnik, R. A., Toon, G. C., Bernath, P. F., Boone, C. D., Walker, K. A., Filipiak, M. J., Harwood, R. S., Fuller, R. A., Manney, G. L., Schwartz, M. J., Daffer, W. H., Drouin, B. J., Cofield, R. E., Cuddy, D. T., Jarnot, R. F., Knosp, B. W., Perun, V. S., Snyder, W. V., Stek, P. C., Thurstans, R. P., and Wagner, P. A.: Validation of Aura Microwave Limb Sounder stratospheric ozone measurements, J. Geophys. Res., 113, D15S20, doi:10.1029/2007JD008771, 2008.

Gebhardt, C., Rozanov, A., Hommel, R., Weber, M., Bovensmann, H., Burrows, J. P., Degenstein, D., Froidevaux, L., and Thompson, A. M.: Stratospheric ozone trends and variability as seen by SCIAMACHY from 2002 to 2012, Atmos. Chem. Phys., 14, 831-846, doi:10.5194/acp-14-831-2014, 2014.

Harvey, V. L., Pierce, R. B., Fairlie, T. D., and Hitchman, M. H.: A climatology of stratospheric polar vortices and anticyclones, J. Geophys. Res., 107, 4444, doi:10.1029/2001JD001471, 2002

Kyrölä, E., Laine, M., Sofieva, V., Tamminen, J., Päivärinta, S.-M., Tukiainen, S., Zawodny, J., and Thomason, L.: Combined SAGE
II-GOMOS ozone profile data set for 1984-2011 and trend analysis of the vertical distribution of ozone, Atmos. Chem. Phys. 13, 10645-10658, doi:10.5194/acp-13-10645-2013, 2013.

Lambert, A., Read,W. G., Livesey, N. J., Santee, M. L., Manney, G. L., Froidevaux, L.,Wu, D. L., Schwartz, M. J., Pumphrey, H. C., Jimenez, C., Nedoluha, G. E., Cofield, R. E., Cuddy, D. T., Daffer, W. H., Drouin, B. J., Fuller, R. A., Jarnot, R. F., Knosp, B. W., Pickett, H. M., Perun, V. S., Snyder, W. V., Stek, P. C., Thurstans, R. P., Wagner, P. A., Waters, J. W., Jucks, K. W., Toon, G. C., Stachnik, R. A., Bernath, P. F., Boone, C. D., Walker, K. A., Urban, J., Murtagh, D., Elkins, J. W., and Atlas, E.: Validation of the Aura Microwave Limb Sounder middle atmosphere water vapor and nitrous oxide measurements, J. Geophys. Res., 112, D24S36, doi:10.1029/2007JD008724, 2007.

Livesey, N. J., Read, W. G., Froidevaux, L., Waters, J. W., Santee, M. L., Pumphrey, H. C., Wu, D. L., Shippony, Z., and Jarnot, R. F.: The UARS Microwave Limb Sounder version 5 data set: theory, characterization, and validation, J. Geophys. Res., 108, 4378, doi:10.1029/2002JD002273, 2003.

Mahieu, E., Chipperfield, M. P., Notholt, J., Reddmann, T., Anderson, J., Bernath, P. F., Blumenstock, T., Coffey, M. T., Dhomse, S. S., Feng, W., Franco, B., Froidevaux, L., Griffith, D. W. T., Hannigan, J. W., Hase, F., Hossaini, R., Jones, N. B., Morino, I., Murata, I., Nakajima, H., Palm, M., Paton-Walsh, C., Russell, J. M., Schneider, M., Servais, C., Smale, D., Walker, K. A.: Recent Northern Hemisphere stratospheric $\mathrm{HCl}$ increase due to atmospheric circulation changes, Nature, 515, 104-107, doi:10.1038/nature13857, 2014.

Nazaryan, H., McCormick, M. P., and Russell III, J. M.: New studies of SAGE II and HALOE ozone profile and longterm change comparisons, J. Geophys. Res., 110, D09305, doi:10.1029/2004JD005425, 2005.

Nedoluha, G. E., Siskind, D. E., Bacmeister, J. T., Bevilacqua, R. M., and Russell III, J. M.: Changes in upper stratospheric $\mathrm{CH}_{4}$ and $\mathrm{NO}_{2}$ as measured by HALOE and implications for changes in transport, Geophys. Res. Lett., 25, 987-990, 1998.

Nedoluha, G. E., Siskind, D. E., Lambert, A., and Boone, C.: The decrease in mid-stratospheric tropical ozone since 1991, Atmos. Chem. Phys., 15, 4215-4224, doi:10.5194/acp-15-4215-2015, 2015.

Parrish, A.: Millimeter-wave remote sensing of ozone and trace constituents in the stratosphere, P. IEEE, 82, 1915-1929, 1994.

Parrish, A., deZafra, R. L., Solomon, P. M., and Barrett, J. W.: A ground-based technique for millimeter wave spectroscopic observations of stratospheric trace constituents, Radio Sci., 23, 106-118, 1988.

Parrish, A., Connor, B. J., Tsou, J. J., McDermid, I. S., and Chu, W. P.: Ground-based microwave monitoring of stratospheric ozone, J. Geophys. Res., 97, 2541-2546, 1992.

Parrish, A., Boyd, I. S., Nedoluha, G. E., Bhartia, P. K., Frith, S. M., Kramarova, N. A., Connor, B. J., Bodeker, G. E., Froidevaux, L., Shiotani, M., and Sakazaki, T.: Diurnal variations of stratospheric ozone measured by ground-based microwave remote sensing at the Mauna Loa NDACC site: measurement validation and GEOSCCM model comparison, Atmos. Chem. Phys., 14, 7255-7272, doi:10.5194/acp-14-7255-2014, 2014.

Randel, W. J. and Wu, F.: Isolation of the ozone QBO in SAGE II data by singular-value decomposition, J. Atmos. Sci., 53, 25462559, 1996. 
Rodgers, C. D.: Retrieval of atmospheric temperature and composition from remote measurements of thermal radiation, Rev. Geophys., 14, 609-624, 1976.

Steinbrecht, W., Claude, H., Schönenborn, F., McDermid, I. S., Leblanc, T., Godin-Beekmann, S., Keckhut, P., Hauchecorne, A., Van Gijsel, J. A. E., Swart, D. P. J., Bodeker, G. E., Parrish, A., Boyd, I. S., Kämpfer, N., Hocke, K., Stolarski, R. S., Frith, S. M., Thomason, L. W., Remsberg, E. E., Von Savigny, C., Rozanov, A., and Burrows, J. P.: Ozone and temperature trends in the upper stratosphere at five stations of the Network for the Detection of Atmospheric Composition Change, Int. J. Remote Sens., 30, 3875-3886, doi:10.1080/01431160902821841, 2009.

Stiller, G. P., von Clarmann, T., Haenel, F., Funke, B., Glatthor, N., Grabowski, U., Kellmann, S., Kiefer, M., Linden, A., Lossow, S., and López-Puertas, M.: Observed temporal evolution of global mean age of stratospheric air for the 2002 to 2010 period, Atmos. Chem. Phys., 12, 3311-3331, doi:10.5194/acp-12-33112012, 2012.
Wang, H. J., Cunnold, D. M., Thomason, L. W., Zawodny, J. M., and Bodeker, G. E.: Assessment of SAGE version 6.1 ozone data quality, J. Geophys. Res., 107, 4691, doi:10.1029/2002JD002418, 2002.

WMO: Global Ozone Research and Monitoring Project Report No. 54, Report of the Ninth Meeting of the Ozone Research Managers of the Parties to the Vienna Convention for the Protection of the Ozone Layer, Geneva, Switzerland, 14-16 May 2014, 2014. 